\title{
Impact of Emotional Intelligence on the Establishment and Development of High Quality Leader Member Exchange (LMX)
}

\author{
Guven Ordun $^{1}$ and Asli Beyhan Acar ${ }^{2}$
}

\begin{abstract}
Leader member exchange (LMX) theory focuses to the dyadic relations between leader and each member. Members are classified into two groups as in-group and out-group members. As out-group members try to fulfill their predefined tasks, in-group members' roles and responsibilities are negotiated and expanded. LMX process can be identified as reciprocal sacrifice. In-group members do more than expected for their leaders and in exchange they get more concern, understanding, help and support from their leaders. Members align with the leaders for several reasons as they like their leaders, they believe in the capabilities or wisdom of their leaders, they identify themselves with the leader or sometimes they are just willing to achieve their own goals or satisfy their own needs in a quicker way. The expectations, needs, values and personalities of the members are assumed to be important as being a member of the in-group. Although emotional intelligence level of the leader is investigated as an antecedent for LMX, researches analyzing the emotional intelligence dimensions of the members are relatively few. This research focus to the emotional intelligence dimensions of the members and investigates the impact of these dimensions on being a member of in-group or out-group.
\end{abstract}

JEL classification numbers: D23, M12, M1

Keywords: Emotional Intelligence (EI), Leader Member Exchange (LMX), contribution, respect, loyalty, affect.

\footnotetext{
${ }^{1}$ Istanbul University, Faculty of Business Administration, Department of Organizational Behavior, Turkey.

${ }^{2}$ Istanbul University, Institute of Business Administration, Turkey.
}

Article Info: Received : January 17, 2014. Revised : February 12, 2014.

Published online : April 10, 2014 


\section{Introduction}

A vertical dyad linkage model has been proposed as an alternative to average leadership styles [1]. This model than progressed into a more effective leadership style depending on the development and maintenance of relations between leaders and each of the members. Leader member exchange theory focuses to the relations between leader and each member. The relations between LMX and performance, satisfaction, commitment, justice perceptions, intention to quit have been analyzed. As the main antecedents and determinants of LMX both the qualities of leader and members or also investigated. Significant relations have been identified depending on the personality characteristics, values, needs and expectations, demographical characteristics of both leaders and members.

Instead of a single vertical dyadic link, multidimensional perspective for LMX proposes affect, loyalty, contribution and professional respect as the main determinants of exchange. There are considerable researches about the relations between high levels of LMX and several organizational and group outcomes such as performance, absenteeism, turnover, commitment and satisfaction.

One of the earliest studies classifies intelligence into three groups as. The first classification of intelligence involves abstract, analytical, verbal intelligence. The second associated with mechanical, performance, visual-spatial intelligence [2]. The third one, social intelligence, has been less studied among all. A part of social intelligence, emotional intelligence involves recognizing emotion, reasoning with both emotion and emotion related information, process this kind of information as a part of problem solving ability [3].Several researchers on leadership argues leadership effectiveness depend on leader's ability to solve complex social problems in organizations. Thus emotional intelligence of the leader considered to be important during the formation and the development of the exchanges in LMX studies. But researches focusing to the emotional intelligence of the group members during this transition period are relatively few in the literature.

Group members have been labeled as in-group and out-group members during the transition period of LMX. The classification depends on the quality of their relations with the leader. As some work more for their leaders and become privileged members others cannot exceed standard definitions of membership. Demographical and personality characteristics, values even abilities of members have been investigated as the determinants of in-group membership.

The main purpose of this study is to analyze the emotional intelligence levels of the group members and investigate if the differences in the emotional intelligence affect in-group membership. The study has been conducted in a retail company with more than 60 stores citywide. 214 section chiefs has answered the both emotional intelligence and leader member exchange questionnaires.

\section{Leader Member Exchange Theory}

Leadership studies can be classified in three broad categories. Several theories as trait approach, charismatic leadership and skills approach focus to the main traits, capabilities and skills of the leader. Identify leaders as specific individuals with privileged inborn qualities. Some behavioral leadership theories like in Hersey-Blanchard's situational 
approach emphasize the follower characteristics and define leaders as the one's match their styles with the needs and expectations of the followers. While theories like vertical dyadic linkage model and leader member exchange theory focus the relation between leaders and members.

Three domain approaches to leadership is discussed in Table 1. The emergence of leadership, the advantages and disadvantages of each perspective is also explained.

Table 1: Three Domain Approaches to Leadership [4]

$\begin{array}{llll} & \begin{array}{l}\text { Leader-Based - } \\ \text { Appropriate behavior of the }\end{array} & \begin{array}{l}\text { Relationship-Based } \\ \text { Trust, respect and mutual } \\ \text { obligation that generates } \\ \text { influence between parties }\end{array} & \begin{array}{l}\text { Follower-Based } \\ \text { Ability and motivation } \\ \text { to manage one’s own }\end{array} \\ \text { What is } & \text { person in leader role } & \end{array}$

What behaviors

Establishing and communicating vision; constitute inspiring, instilling pride

Building strong relationship with

Empowering, followers; mutual learning giving up control leadership? and accommodation
Advantages
Leader as rallying point for organization; common understanding of mission and values; can initiate wholesale change

Accommodates differing Makes the most needs of subordinates; can follower capabilities; elicit superior work from frees up leaders for different types of people other responsibilities

Disadvantages

Highly dependent on leader; problems if leader changes or is pursuing inappropriate vision

Time-consuming; relie

When

Fundamental change; charismatic leader in place; limited diversity among followers

Where most Structured tasks; strong effective?

$$
\begin{aligned}
& \text { leader position power; } \\
& \text { member acceptance of } \\
& \text { leader }
\end{aligned}
$$
between specific leaders and members

Continuous improvement teamwork; substantial diversity and stability among followers; network building

\author{
Highly capable and \\ task committed \\ followers
} follower initiative and ability

Situation favorability for leader between two extremes
Unstructured tasks; weak position power, member nonacceptance of leader

Leader-member exchange (LMX) theory conceptualizes leadership as process that is understood by the quality of interactions and opportunities surrounding the dyadic relationships between leaders and their members. While most leadership research focused on identifying best practices for optimizing organizational outcomes (e.g., satisfaction, motivation, goal attainment) LMX research describes the leadership dynamics that take place implicitly and explicitly in organizations [5].

High quality LMX refers to the strength or the bound between leader and each of the members. Although there is no real division or even discrimination between members 
depending on the strength of the relations, group members can be categorized as in-group or out-group.

High quality LMX relationships are characterized by such attributes as mutual trust, respect, liking eachother, extra-role behavioral exchanges, and higherlevels of emotional support. Low quality LMX is at the opposite end of the continuum and can be characterized as being transactional in nature, with the two parties engaging in a more strictly role-defined, top-down relationship [6].

LMX theory essentially states that supervisors treat their subordinates differently; some members receive more favorable treatment than others. Increased job satisfaction, higher performance ratings, higher levels of delegation, salary progression, higher promotion opportunities, career satisfaction, supply of resources and support for innovative behavior assumed to be the positive outcomes of these members [7].

Supervisor-subordinate exchanges that are higher quality are close working relationships characterized by trust and support, interpersonal attraction, loyalty, and mutual influence. Higher quality exchange subordinates are also referred as "in-group". Others do not engage behaviors that exceeds their standard role definitions become labeled as "out group".

Since high quality LMX is related to positive outcomes for employees, it can be expected that they will receive more of what was initially promised to them and therefore it can also be expected that they would be more inclined to perceive their psychological contract as having been fulfilled [7]. In general, the quality of a leader-follower relationship will determine how both parties, leaders and followers, experience their work and engage in it - with perceived relationship quality consequently being positively related to organizationally relevant and desirable outcomes [8].

Mankins[9] proposes the idea that organizations willing to be effective should focus on core activities and minimize the amount of time on noncore activities. Relationship between leaders and followers are time consuming and perceived as not being essential for organizational productivity. But considerable amount of research has been conducted in order to analyze especially the positive outcomes of high quality LMX. As some of the researchers focus to the positive outcomes of the organization such as performance, effectiveness, productivity [10];[11],some focus to the group level and analyze concepts as teamwork, cohesiveness and conflict [12]; [13];[14], while the rest of the researchers try explain the effects of LMX on individual level, such as perception of fairness satisfaction, commitment, prosocial and counterproductive work behavior [15]; [16]. Schriesheim et al. [17] conducted a meta analytic study in order to define the main antecedents and the consequences of LMX. Traditionally, LMX has been treated as a global construct that represents a measure of the general quality of the exchange relationship between a supervisor and a subordinate. More recently, however, Dienesch and Liden[18] argued that there is no clear theoretical or empirical justification for the traditional conceptualization of LMX as a unidimensional construct. They maintained that the theoretical bases of LMX theory (e.g., role theory, social exchange theory) are more consistent with a multidimensional perspective.Dienesch\&Liden (1986) and Liden\&Maslyn (1998) [19] proposed four dimensions of LMX relationships labeled "contribution" (e.g., performing work beyond what is specified in the job description); "affect" (e.g., friendship and liking); loyalty (e.g., loyalty and mutual obligation) and professional respect (e.g., respect for professional capabilities). Identifying these four dimensions of leader-member relationships is important because relationships, which differ in their exchange currencies, also may have different antecedents and consequences 
[20].These dimensions, which they did not propose to be exhaustive, are "contribution," or the in-role and extra-role tasks that the subordinate completes for the supervisor; "loyalty," which is exemplified by the degree to which the subordinate and supervisor are willing to publicly support one another; "affect" or the degree to which the subordinate and supervisor mutually like each other based on interpersonal attraction; and "professional respect" or the degree to which each member of the dyad perceives the other as excelling at his or her work [6].

The dimensions of LMX that mentioned above and their brief definitions are in Table 2.

\section{Table 2: LMX Dimensions Definitions [19]}

\begin{tabular}{l|l} 
Affect & $\begin{array}{l}\text { The mutual affection members of the dyad have for each other based } \\
\text { primarily on interpersonal attraction, rather than work or } \\
\text { professional values. Such affection may be manifested in the desire } \\
\text { for and/or occurrence of a relationship, which has personally } \\
\text { rewarding components and outcomes (e.g., a friendship). }\end{array}$ \\
\hline Loyalty & $\begin{array}{l}\text { The expression of public support for the goals and the personal } \\
\text { character of the other member in the LMX dyad. Loyalty involves } \\
\text { faithfulness to the individual that is generally consistent from } \\
\text { situation to situation. }\end{array}$ \\
\hline Contribution & $\begin{array}{l}\text { Perception of the current level of work-oriented activity each } \\
\text { member puts forth toward the mutual goals (explicit or implicit) of } \\
\text { the dyad. Important in the evaluation of work-oriented activity is the } \\
\text { extent to which the subordinate member of the dyad handles } \\
\text { responsibility and completes tasks that extend beyond the job } \\
\text { description and/or employment contract; and likewise, the extent to } \\
\text { which the supervisor provides resources and opportunities for such } \\
\text { activity. }\end{array}$ \\
\hline $\begin{array}{l}\text { Perception of the degree to which each member of the dyad has built } \\
\text { a reputation, within and/or outside the organization, of excelling at } \\
\text { his or her line of work. This perception may be based on historical } \\
\text { data concerning the person, such as: personal experience with the } \\
\text { individual; comments made about the person from individuals } \\
\text { within or outside the organization; and awards or other professional } \\
\text { recognition achieved by the person. Thus it is possible, though not } \\
\text { required, to have developed a perception of professional respect } \\
\text { before working with or even meeting the person. }\end{array}$ \\
\hline
\end{tabular}

Although the dimensions of LMX refers to the relations between leader and each of his/her member, emotionality is considered to be an important issue that affects the quality of the exchanges, effectiveness of the leader and evaluations of followers.

\section{The Concept and the Dimensions of Emotional Intelligence}

There are several definitions for emotions in the literature. Emotions can be defined as notions of feelings, fluctuations in the control of behavior, appraisals of experiences, physiological arousal and expression [21].

One tradition in psychology emotional and logical thoughts are perceived as opposite to one another. From this point of view emotion is seen as disrupting, misdirecting and 
interfering with attempts to functional rationally in the world. But a competing argument has viewed emotion as part of and contributor to logical thought and intelligence and it has been referred as emotional intelligence. Emotional intelligence is described as a type of emotional information processing that includes accurate appraisal of emotions in oneself and others, appropriate expression of emotion and adaptive regulation of emotion in such a way as to enhance living [22].

Salovey and Mayer [23] define emotional intelligence as the subset of social intelligences that involve the ability to monitor one's own and others' feelings and emotions, to discriminate among them, and to use this information to guide one's thinkingand actions. Logical and Emotional Intelligence are not the opposite sides but considered to be distinct capabilities. In fact several dimensions of logical and emotional capabilities are related with each other but as this relation is so limited it is argued that logical and emotional intelligence is distinct concepts [24].

Emotional intelligence involves the capacity to carry out reasoning in regard to emotions, and the capacity of emotions to enhance reasoning. More specifically, EI is said to involve the ability to perceive and accurately express emotion, to use emotion to facilitate thought, to understand emotions, and to manage emotions for emotional growth. A number of related concepts exist, including emotional competence, emotional creativity, and empathic accuracy [25].

Perceiving emotions introduces the ability to accurately identify emotions in oneself and others, using cues from facial expressions, voice, or gestures. Using emotions denotes the ability to generate, use, and feel emotion as necessary to communicate feelings or employ them in other cognitive processes. Understanding emotions entails the ability to understand their causes, and consequences and how they change over time. EI also involves the management of emotions in oneself and others [26].

Goleman [27] based on Salovey and Mayer's definition, and identifies five emotional competencies:

- The ability to identify and name one's emotional states and to understand the link between emotions, thought and action

- The capacity to manage one's emotional states - to control emotions or to shift undesirable emotional states to more adequate ones

- The ability to enter into emotional states (at will) associated with a drive to achieve and be successful

- The capacity to read, be sensitive to and influence other people's emotions

- The ability to enter and sustain satisfactory interpersonal relationships.

The table below lists Golemans' 5 components of emotional intelligence and the 25 emotional competencies: 
Table 3: Goleman's 5 Components of Emotional Intelligence and the 25 Emotional Competencies [28]

\begin{tabular}{|c|c|c|}
\hline \multicolumn{3}{|c|}{ PERSONAL COMPETENCE } \\
\hline SELF-AWARENESS & $\begin{array}{l}\text { Observing yourself and recognizing } \\
\text { your feelings; building a vocabulary for } \\
\text { feelings; knowing the relationship } \\
\text { between thoughts, feelings and } \\
\text { reactions. }\end{array}$ & $\begin{array}{l}\text { Emotional Awareness: } \\
\text { recognizing one's emotions } \\
\text { and their effect } \\
\text { Accurate Self-Assessment: } \\
\text { knowing one's strengths } \\
\text { and limits } \\
\text { Self-confidence: A strong } \\
\text { sense of one's self-worth }\end{array}$ \\
\hline \multirow[t]{5}{*}{ SELF-REGULATION } & \multirow[t]{5}{*}{$\begin{array}{l}\text { Managing one's internal states, } \\
\text { impulses, and resources }\end{array}$} & $\begin{array}{l}\text { Self-control: Keeping } \\
\text { disruptive emotions and } \\
\text { impulses in check }\end{array}$ \\
\hline & & \begin{tabular}{|l|} 
Trustworthiness: \\
Maintaining standards of \\
honesty and integrity
\end{tabular} \\
\hline & & $\begin{array}{l}\text { Conscientiousness: Taking } \\
\text { responsibility for personal } \\
\text { performance }\end{array}$ \\
\hline & & $\begin{array}{l}\text { Adaptability: Flexibility in } \\
\text { handling change }\end{array}$ \\
\hline & & $\begin{array}{l}\text { Innovation: Being } \\
\text { comfortable with novel } \\
\text { ideas, approaches and new } \\
\text { information }\end{array}$ \\
\hline \multirow[t]{4}{*}{ MOTIVATION } & \multirow[t]{4}{*}{$\begin{array}{l}\text { Emotional tendencies that guide or } \\
\text { facilitate reaching goals }\end{array}$} & \begin{tabular}{|l} 
Achievement Drive: \\
Striving to improve or meet \\
a standard of excellence
\end{tabular} \\
\hline & & $\begin{array}{l}\text { Commitment: Aligning } \\
\text { with the goals of the group } \\
\text { or organization }\end{array}$ \\
\hline & & $\begin{array}{l}\text { Initiative: Readiness to act } \\
\text { on opportunities }\end{array}$ \\
\hline & & $\begin{array}{l}\text { Optimism: Persistence in } \\
\text { pursuing goals despite } \\
\text { obstacles and setbacks }\end{array}$ \\
\hline \multicolumn{3}{|c|}{ SOCIAL COMPETENCE } \\
\hline \multirow[t]{4}{*}{ EMPATHY } & \multirow[t]{4}{*}{$\begin{array}{l}\text { Awareness of others' feelings, needs } \\
\text { and concerns. }\end{array}$} & $\begin{array}{l}\text { Understanding Others: } \\
\text { sensing others' feelings } \\
\text { and perspectives, taking } \\
\text { an active interest in their } \\
\text { concerns } \\
\end{array}$ \\
\hline & & \begin{tabular}{|l} 
Developing others: \\
Sensing others \\
development needs and \\
bolstering their abilities \\
\end{tabular} \\
\hline & & $\begin{array}{l}\text { Service Orientation: } \\
\text { Anticipating, recognizing, } \\
\text { and meeting customers' } \\
\text { needs } \\
\end{array}$ \\
\hline & & \begin{tabular}{|l} 
Leveraging Diversity: \\
\end{tabular} \\
\hline
\end{tabular}




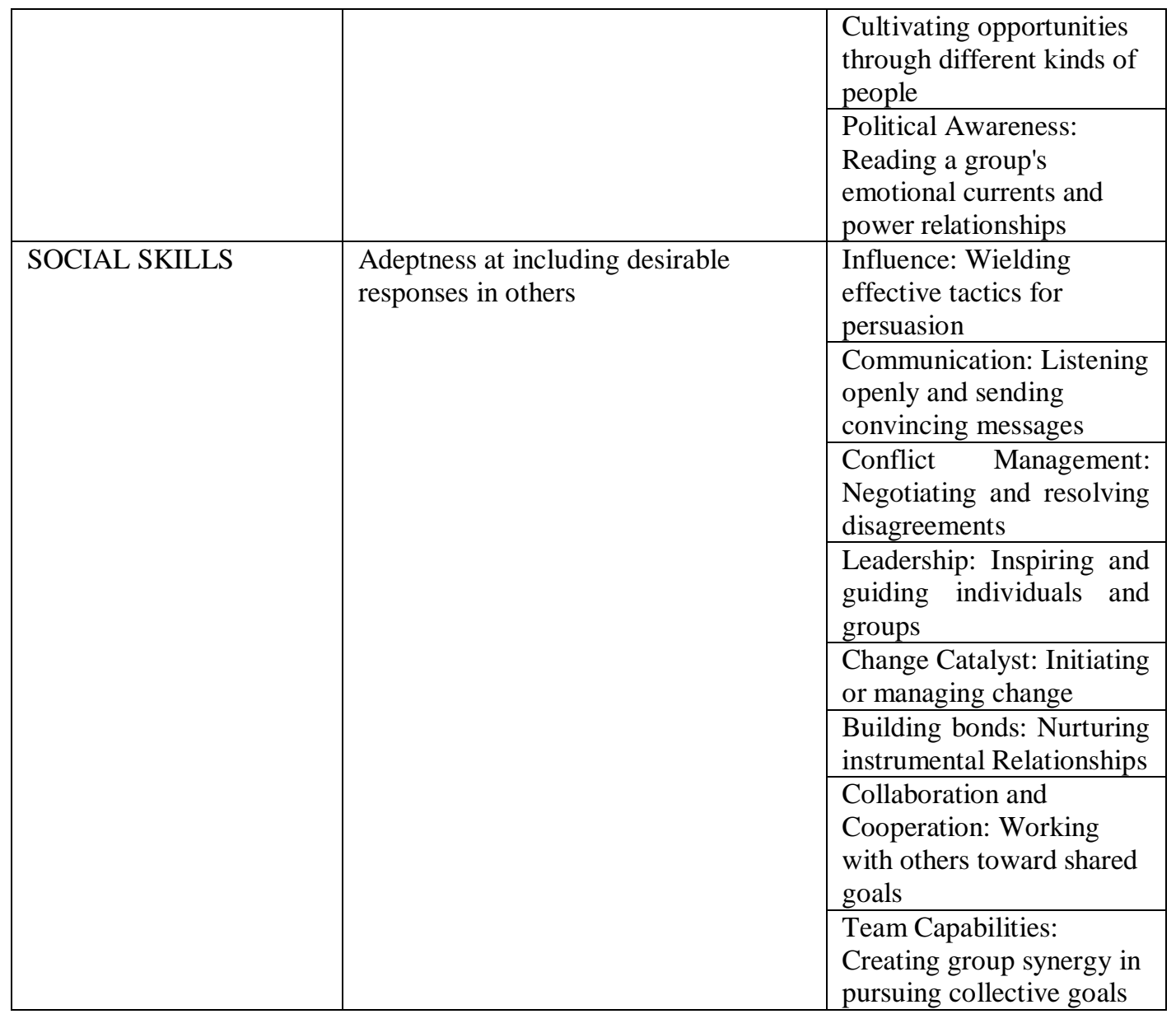

Personal and social competencies are defined as the main classifications of Emotional Intelligence. In Table 3 and Table 4 the sub dimensions and the brief explanations are defined.

\section{Emotional Intelligence at Workplace}

Mayer and Salovey [29] argue that emotional intelligence abilities enable individuals to recognize, understand and manage emotions in themselves and others that contribute better relationships in the workplace.

In agreement with Mayer and Salovey, Cooper and Sawaf $(1997,1998)$ asserted that many of the people with a higher Intelligence Quotient (IQ) (therefore considered intellectually more intelligent) would not consistently succeed in their personal or professional life, due to the scarcity of control over their emotions, or, opposite to this, they could manage a full control over their emotions and anxiety, but not be able to emotionally "tune in" with the others [30].

Emotional intelligence (EI) claims to offer much to businesses of the 21st century with benefits including improved performance and productivity. For instance, EI predicts group performance, organizational citizenship behavior. In management roles, Francis 
and Keegan (2006) note the line manager is now increasingly responsible for absence management, grievance handling, discipline issues, and counseling employees as well as appraisal and selection activities, general motivation, and coaching. These are roles that require EI, particularly in relation to empathy, emotional awareness, and managing emotions [26].

Several studies have shown that EI affects teamwork and interpersonal relationship at work. People with high EI are socially perspective at recognizing and understanding the feelings and emotions in their team and induce positive emotions and attitudes in others. If EI facilitates effective interpersonal exchanges at work, it may be considered a prerequisite for group task coordination and leadership emergence [31].

The influence of EI begins with the retention and recruitment of talent. For instance, as Claudio Fernández-Aráoz points out, the extent to which candidates'emotional intelligence isconsidered inmaking top executive hiring decisions has a significant impact on the ultimate success or failure of those executives. The emotional intelligence of the employees, doing the hiring is also crucial for good hiring decisions [32].

Emotional intelligence creates utile explicabilities to the workplace, both within the teamwork than the relations to the clients. One example of this theory can be seen in the concern for challenges and obstacles, or lack of motivation or various difficulties that can hinder the full achievement of the individuals [30].

Research on leadership effectiveness focuses on efforts to explain factors affecting leadership in one-way or another. While some researchers focus mainly on the leader's individual traits, value system, morality, and authenticity, others prefer to focus on leadership behaviors and styles, such as task versus-people orientation, transformational, transactional, laissez-faire, or servant-leadership behavior and style. Leadership effectiveness as a dependent variable has also been linked to a vast number of situational variables, including the role of culture, the attributes of followers, and followers' perceptions [33].

A person with high EI is able to interpret his or her own mood as well as others' moods, correctly, and therefore has a higher chance of forming good relationships and getting social support in general [31].

Several researches emphasize the relations between the dimension of EI and leadership[34]; [35]; [36]; [37]). Lanser (2000) places a strong emphasis on the importance of self-awareness in guiding and perfecting job performance, including interactions with colleagues and in the establishment of positive and productive leadership and teamwork skillsSelf-awareness of emotions enables team members to then practice self-regulation, which is the ability to use emotions to facilitate the progress of the task or the project. Successful teamwork requires intrinsic motivation, persistence and vision. Goleman (1998) contends that empathy is understanding and interpreting colleagues' feelings and being able to identify with their feelings on issues through understanding their perspective and cultivating rapport with people from different 'walks of life'. Also team members need to be able to stimulate cooperation, collaboration and teamwork through well-developed social skills [38].

Pescosolido[39] propose a new role for emergent group leaders, that of the manager of group emotions. The members who provide certainty and direction during times of uncertainty may take the leadership. They are able to assume a leadership role by making an interpretation of emotional response that best serves the groups' needs and then modeling that response. 
Sosik and Megerian[40]studied the relationship between transformational leadership behavior, emotional intelligence, and leader effectiveness. They examine self-awareness in terms of self- other agreement and private and public self-consciousness. They found that categorizations of self-awareness are correlated between emotional intelligence of leadership and leadership behavior. Subordinate ratings of transformational leadership behavior are positively related to those leaders categorized as self-aware. They concluded "managers who maintain self-awareness (self-other rating agreement) possess more aspects of emotional intelligence and are rated as more effective by both superiors and subordinates than those who are not self-aware".

\section{Research Methodology}

\subsection{Purpose and Importance of the Study}

It has been argued that emotional intelligence would have a direct effect on the quality of LMX. LMX depends on emotional interchanges. Dasborough and Ashkanasy [41]define the importance of leaders emotional displays on the establishment and development of the relationship with the followers. And Kellett [42]found significant relations between followers perceptions of leaders displayed emotions and leadership emergence. Jordan and Troth [43] proposed the suggestion that higher level of follower emotional intelligence would be associated with higher perceived levels of quality LMXs by followers.

First of all this research focus to the emotional intelligence dimensions of the members and investigates the impact of these dimensions on being a member of in-group or outgroup. Then we would like to find out the relations between the dimensions of Emotional Intelligence and the dimensions of LMX and the impact of EI on the variables of LMX. There are considerable researches investigate the impact of emotional intelligence of the leader on the LMX relations. But researches focusing the emotionality of the members on the quality of LMX are relatively few. Thus most of the researches emphasize the unidimensionality of the LMX. Multidimensional perspective for LMX both focus to the expanded relations between leader and each member as well as negotiated and accepted roles and responsibilities beyond their formal role descriptions. We also would like to find out if same or different variables of EI (whether self or other) affect the relations and role dimensions of LMX.

\subsection{Variables and the Hypothesis of the Study}

Emotional Intelligence is measured using the 16 items from Wong and Law Emotional Intelligence Scale (WLEIS: Wong \& Law, 2002)[44]. WLEIS is consistent with Mayer and Salovey's conceptualization of emotional intelligence. 7 point scale is used in WLEIS as 1: least accepted and 7: most accepted. LMX dimensions and the quality of LMX are measured using 12 items multidimensional model of leader member exchange (LMXMDM) from Liden and Maslyn[19].5 point scale is used in LMX as 1: absolutely disagree and 5: absolutely agree. Although most of the LMX studies prefer a unidimensional measure of LMX, as we would like to find out the impact of EI on both relations and feelings of obligations, a multidimensional scale is preferred. 
Variables determined for EI as Self Emotional Appraisal, Others' Emotional Appraisal, Use of Emotion and Regulation of Emotion and for LMX as affect, Loyalty, Contribution and Professional Respect.

Hypothesis 1: The EI levels of the members are different between in-group and outgroup. Mayer and Salovey argue that emotional intelligence abilities enable individuals to recognize, understand and manage emotions in themselves and others, and this contributes to better relationships in the workplace. LMX classifies the group members as in-group and out-group depending on the strength of the link or the quality of the relations between leader and each member. High quality LMX refers to the expanded and negotiated relations, roles and responsibilities while low quality LMX define relations and responsibilities depending on the formal contract. Although LMX emphasizes the link between leader and each member we would like to test the idea if the Emotional Intelligence levels of the members affects the quality of relations between themselves and their leader.

Hypothesis 2: The variables of EI are correlated with the variables of LMX.

Self Emotional Appraisal, Others' Emotional Appraisal, Use of Emotion and Regulation of Emotion are the main variables of WLEIS. Affect, Loyalty, Contribution and Professional Respect are the variables of LMX-MDM. WE would like to find out the relations between each EI variable and any variable of LMX.

Hypothesis 3: Affect, Loyalty, Contribution and Professional Respect is affected by the dimensions of EI.

LMX can be analyzed on either dyadic relations or behaviors. If the level of commitment on their leader is described as relational perspective of members LMX, their expanded behaviors beyond formal role descriptions can be defined as the behavioral perspective of member LMX. We would like to test the idea if self - other appraisal of emotions or use regulation of emotions has an affect on the variables of LMX from the perspective of members.

\subsection{Participants and Method}

214 section chiefs of a retail company with 60 groceries have been participated in the study which 147 of man (68.4\%) and 67 of woman (31.2\%). 105 participants (\%48.8) is between the age of $18-27,102(47.4 \%)$ between 28 - 40 and 7 (3.3 \%) with the age of 41 and above. 119 participants (55.6\%) are married and 95 (44.4\%) of them are single. $128(59.5 \%)$ of them are high school graduates while 42 (19.5\%) graduated from primary school, 41 (19.1\%) of them has a bachelor degree and $3(1.4 \%)$ has a masters degree. 65 (30.2\%) of the employees have been working within the company less than 3 years, 78 (36.3\%) between 3 to 6 years, 67 (31.2 \%) between 6 to 10 years, 4 (1.9\%) employees have more than 10 year tenure within the organization.

Depending on the variations of the geographical locations, both scales have been distributed and collected by the help of human resources department. As no names are required in any of the scales, codes are printed on the scales in order to match EI and LMX scales and differentiate the stores with each other.

\subsection{Results}

While low quality LMX (out-group) is associated with formal contracts, predefined roles and relations, in high quality LMX (in-group) relations between leader and each member 
is negotiated and expanded. In-group membership requires engaging in extra roles and taking extra responsibilities. LMX dimensions are defined as affect (eg. I like my supervisor very much as a person.), loyalty (eg. My supervisor defends my work actions to a superior, even without complete knowledge of the issue in question.), contribution (eg. I do work for my supervisor that goes beyond what is specified in my job description.) and professional respect (eg. I am impressed with my supervisor's knowledge of his/her job.).

Table 4: Comparison of In/Out-Group Members on Dimension of LMX

\begin{tabular}{|c|c|c|c|c|c|}
\hline & Group & Mean & Std. Deviation & $\mathrm{t}$ & $\begin{array}{c}\text { Sig. } \\
\text { (2-tailed) }\end{array}$ \\
\hline \multirow{2}{*}{ Affect } & Out-Group & 3.56 & .96 & \multirow{2}{*}{-10.384} & \multirow{2}{*}{.000} \\
\hline & In-Group & 4.64 & .42 & & \\
\hline \multirow{2}{*}{ Loyalty } & Out-Group & 2.91 & .93 & \multirow{2}{*}{-13.566} & \multirow{2}{*}{.000} \\
\hline & In-Group & 4.38 & .58 & & \\
\hline \multirow{2}{*}{ Contribution } & Out-Group & 3.54 & 1.04 & \multirow{2}{*}{-9.776} & \multirow{2}{*}{.000} \\
\hline & In-Group & 4.62 & .39 & & \\
\hline Professional & Out-Group & 3.47 & 1.02 & \multirow{2}{*}{-10.530} & \multirow{2}{*}{.000} \\
\hline Respect & In-Group & 4.62 & .42 & & \\
\hline
\end{tabular}

In each dimension of LMX, the mean differences between in-group and out-group members are significant. The highest difference is calculated in loyalty (out-group, $\mathrm{n}=103$, mean=2.91, std. dev. .93 and in-group, $\mathrm{n}=111$, mean $=4.38$, std. dev. $=.58 ; \mathrm{t}=-$ 13.566, sig.= 0.000). In-group members are more committed and loyal to their leaders. Lee (2005) [45] argues that high quality LMX and loyalty to the leader facilitates the commitment of the employee to the organization. High quality LMX decreases the level of employee turnover and increases the level of organizational commitment.

Table 5: Comparison of In/Out-Group Members on Dimensions of EI

\begin{tabular}{|c|c|c|c|c|c|}
\hline & Group & Mean & $\begin{array}{c}\text { Std. } \\
\text { Deviation }\end{array}$ & $\mathrm{t}$ & $\begin{array}{c}\text { Sig. } \\
\text { (2-tailed) }\end{array}$ \\
\hline \multirow{2}{*}{$\begin{array}{l}\text { Others' Emotion } \\
\text { Appraisal }\end{array}$} & Out-Group & 5.35 & 1.47 & \multirow{2}{*}{-3.320} & \multirow{2}{*}{.001} \\
\hline & In-Group & 5.97 & 1.18 & & \\
\hline \multirow{2}{*}{ Use of Emotion } & Out-Group & 5.59 & 1.51 & \multirow{2}{*}{-3.920} & \multirow{2}{*}{.000} \\
\hline & In-Group & 6.29 & 1.02 & & \\
\hline \multirow{2}{*}{ Regulation of Emotion } & Out-Group & 5.38 & 1.67 & \multirow{2}{*}{-3.834} & \multirow{2}{*}{.000} \\
\hline & In-Group & 6.13 & 1.12 & & \\
\hline \multirow{2}{*}{ Self Emotion Appraisal } & Out-Group & 5.44 & 1.66 & \multirow{2}{*}{-3.447} & \multirow{2}{*}{.001} \\
\hline & In-Group & 6.12 & 1.13 & & \\
\hline
\end{tabular}

In-group and out-group members are compared depending on their scores for the dimensions of EI. In every dimension of EI the mean differences between in-group and out-group members are calculated as significant. So Hypothesis 1 (The EI levels of the members are different between in-group and out-group.) is accepted. EI Dimensions are defined as Self Emotional Appraisal (eg. I have a good sense of why I have certain feelings most of the time.), Others’ Emotional Appraisal (eg. I always know my friends' 
emotions from their behavior.), Use of Emotion (eg. I would always encourage myself to try my best.), and Regulation of Emotion (eg. I am able to control my temper and handle difficulties rationally.) The highest differences appear in Use of Emotion and Regulation of Emotion in which the dimensions are directed to explain the relations between emotions and behaviors.

Table 6: Correlation Analysis of Dimensions

\begin{tabular}{|c|c|c|c|c|c|c|c|c|}
\hline & Mean & 1 & 2 & 3 & 4 & 5 & 6 & 7 \\
\hline $\begin{array}{l}\text { Others' } \\
\text { Emotion } \\
\text { Appraisal (1) }\end{array}$ & 5.67 & 1 & & & & & & \\
\hline $\begin{array}{l}\text { Use of Emotion } \\
(2)\end{array}$ & 5.95 & $.701^{* *}$ & 1 & & & & & \\
\hline $\begin{array}{l}\text { Regulation of } \\
\text { Emotion (3) }\end{array}$ & 5.77 & $.670^{* *}$ & $.823^{* *}$ & 1 & & & & \\
\hline $\begin{array}{l}\text { Self Emotion } \\
\text { Appraisal (4) }\end{array}$ & 5.80 & $.777^{* *}$ & $.757^{* *}$ & $.768^{* *}$ & 1 & & & \\
\hline Affect (5) & 4.12 & $.376^{* *}$ & $.462^{* *}$ & $.438^{* *}$ & $.438^{* *}$ & 1 & & \\
\hline Loyalty (6) & 3.67 & $.289^{* *}$ & $.294^{* *}$ & $.327^{* *}$ & $.266^{* *}$ & $.621^{* *}$ & 1 & \\
\hline $\begin{array}{l}\text { Contribution } \\
\text { (7) }\end{array}$ & 4.10 & $.431^{* *}$ & $.526^{* *}$ & $.532^{* *}$ & $.457^{* *}$ & $.624^{* *}$ & $.574^{* *}$ & 1 \\
\hline $\begin{array}{l}\text { Professional } \\
\text { Respect (8) }\end{array}$ & 4.07 & $.497^{* *}$ & $.532^{* *}$ & $.539^{* *}$ & $.548^{* *}$ & $.723^{* *}$ & $.589^{* *}$ & $.689^{* *}$ \\
\hline
\end{tabular}

** Correlation is significant at the 0.01 Level (2 - Tailed)

The main dimensions of WLEIS and LMX-MDM are positively correlated with each other. The highest levels of correlation are calculated between professional respect and self-emotional appraisal (cor. $=.548$, sig. $=.00$ ), contribution and regulation of emotions (cor. $=.532$, sig. $=.00$ ). Depending on the results the second hypothesis (The variables of EI are correlated with the variables of LMX) is accepted. 
Table 7: Regression Analysis of Dimensions

\begin{tabular}{|c|c|c|c|c|}
\hline \multicolumn{5}{|c|}{ AFFECT } \\
\hline Model & $\mathrm{R}$ & R Square & $\mathrm{F}$ & Sig. \\
\hline 1 & $.462^{\mathrm{a}}$ & .213 & 57.524 & $.000^{\mathrm{b}}$ \\
\hline a.b. Pre & Constar & of Emotio & & \\
\hline \multicolumn{5}{|c|}{ LOYALTY } \\
\hline Model & $\mathrm{R}$ & R Square & $\mathrm{F}$ & Sig. \\
\hline 1 & $.327^{\mathrm{a}}$ & .107 & 25.450 & $.000^{\mathrm{b}}$ \\
\hline \multicolumn{5}{|c|}{ a.b. Predictors: (Constant), Regulation of Emotion } \\
\hline \multicolumn{5}{|c|}{ CONTRIBUTION } \\
\hline Model & $\mathrm{R}$ & R Square & $\mathrm{F}$ & Sig. \\
\hline & $.532^{\mathrm{a}}$ & .283 & 83.630 & $.000^{\mathrm{b}}$ \\
\hline \multicolumn{5}{|c|}{ a.b. Predictors: (Constant), Regulation of Emotion } \\
\hline \multicolumn{5}{|c|}{ PROFESSIONAL RESPECT } \\
\hline$\overline{\text { Model }}$ & $\mathrm{R}$ & R Square & $\mathrm{F}$ & Sig. \\
\hline 1 & $.548^{\mathrm{a}}$ & .301 & 91.173 & $.000^{\mathrm{b}}$ \\
\hline
\end{tabular}

a.b. Predictors: (Constant), Self Emotion Appraisal

Stepwise regression method is used in order to calculate the impact of each dimension of EI on each dimension of LMX. Use of Emotions assumed to have the highest impact on the Affect dimension of $\operatorname{LMX}(\mathrm{R} .=.46$, R Sq. $=.21)$, Regulation of Emotion both on Loyalty $(\mathrm{R} .=.33$, R Sq. .11$)$, and Contribution $(\mathrm{R} .=.53, \mathrm{R}$ Sq.= .28), Self Emotional Appraisal on Professional Respect (R.= .55, R Sq.= .30).

Table 8: Coefficient Scores For Dimensions

\begin{tabular}{|c|c|c|c|c|c|c|}
\hline \multirow{2}{*}{\multicolumn{2}{|c|}{ Model }} & \multicolumn{2}{|c|}{$\begin{array}{l}\text { Unstandardized } \\
\text { Coefficients }\end{array}$} & \multirow{3}{*}{$\begin{array}{c}\text { Standardized } \\
\text { Coefficients } \\
\text { Beta }\end{array}$} & \multirow[t]{2}{*}{$\mathrm{t}$} & \multirow[t]{2}{*}{ Sig. } \\
\hline & & $\mathrm{B}$ & Std. Error & & & \\
\hline & (Constant) & 2.245 & .254 & & 8.835 & .000 \\
\hline 1 & Use of Emotion & .316 & .042 & .462 & 7.584 & .000 \\
\hline \multicolumn{7}{|c|}{ Dependent Variable: AFFECT } \\
\hline \multicolumn{2}{|c|}{ Model } & \multicolumn{2}{|c|}{$\begin{array}{l}\text { Unstandardized } \\
\text { Coefficients }\end{array}$} & $\begin{array}{l}\text { Standardized } \\
\text { Coefficients }\end{array}$ & $\mathrm{t}$ & Sig. \\
\hline & (Constant) & $\begin{array}{c}\text { B } \\
2.298\end{array}$ & $\begin{array}{l}\text { Std. Error } \\
.282\end{array}$ & Beta & 8.145 & .000 \\
\hline 1 & $\begin{array}{l}\text { Regulation of } \\
\text { Emotion }\end{array}$ & .239 & .047 & .327 & 5.045 & .000 \\
\hline \multicolumn{7}{|c|}{ Dependent Variable: LOYALTY } \\
\hline \multirow{2}{*}{\multicolumn{2}{|c|}{ Model }} & \multicolumn{2}{|c|}{$\begin{array}{l}\text { Unstandardized } \\
\text { Coefficients }\end{array}$} & $\begin{array}{l}\text { Standardized } \\
\text { Coefficients }\end{array}$ & $\mathrm{t}$ & Sig. \\
\hline & & $\begin{array}{c}\text { B } \\
2.111\end{array}$ & $\begin{array}{l}\text { Std. Error } \\
.225\end{array}$ & Beta & 9.388 & .000 \\
\hline 1 & $\begin{array}{l}\text { Regulation of } \\
\text { Emotion }\end{array}$ & .345 & .038 & .532 & 9.145 & .000 \\
\hline
\end{tabular}




\begin{tabular}{|c|c|c|c|c|c|}
\hline \multicolumn{6}{|c|}{ Dependent Variable: CONTRIBUTION } \\
\hline Model & $\begin{array}{r}\text { Unst } \\
\text { Co }\end{array}$ & $\begin{array}{l}\text { Irdized } \\
\text { ients }\end{array}$ & $\begin{array}{l}\text { Standardized } \\
\text { Coefficients }\end{array}$ & $\mathrm{t}$ & Sig. \\
\hline \multirow{3}{*}{$1 \begin{array}{l}\text { (Constant) } \\
\text { Self Emotion } \\
\text { Appraisal }\end{array}$} & B & Std. Error & Beta & & \\
\hline & 1.970 & .227 & & 8.686 & .000 \\
\hline & .362 & .038 & .548 & 9.548 & .000 \\
\hline
\end{tabular}

The impacts of each dimension of EI on LMX dimension are calculated. The third hypothesis (Affect, Loyalty, Contribution and Professional Respect is affected by the dimensions of EI.) is accepted. Use of Emotion has an impact on the level of Affect dimension, Regulation of Emotions seems to have an important role both on Loyalty and the Contribution dimensions, Self Emotional Appraisal has an impact on the dimension of Professional Respect. Although Others' Emotional Appraisal is correlated with all dimensions of LMX the impact of this variable seems to be not significant on each of the LMX dimensions. Contribution dimension is related with taking extra roles and responsibilities so it can be identified as one of the core dimensions on the definition of high quality LMX. Regulation of Emotions (controlling one's emotions) assumed to have the significant impact on the level of contribution dimension. So instead of controlling the emotions, making quick decisions and engaging acts depending on the urges of the emotions assumed to be negatively correlated with the level of Contribution as well as the high quality LMX.

\section{Conclusions}

Leadership is one of the most interested and analyzed concepts in social sciences. Several theories focus to the leader qualities and characteristics while some emphasize the behaviors of the leaders that fulfill the needs and expectations of the followers. LMX theory emphasizes the relations between leader and each member. Low quality LMX depends on formal contracts, predefined roles and responsibilities. High quality LMX exceeds any formal description orexpectation and explained as negotiated - expanded roles and responsibilities between leader and members of in-group. Actually high quality relations depend on reciprocal benefits for both leader and each member.

The role of emotions has to be clarified on the effectiveness and the quality of relations. Several researchers are directed to explain the impact of Emotional Intelligence on the effectiveness of the leader and his/her relations with the members but relatively few studies deal with the Emotional Intelligence levels of the members. High quality LMX can be defined as a strong dyadic link between the leader and each member. Emotional Intelligence can be classified as awareness of self and awareness of the other emotions. And how to control and use one's self emotions is another important part of the classification.

First we have tested the relation of emotional intelligence dimensions on the determination of high quality LMX. In-group members have significantly higher scores on each EI dimension. Then we have tested the impact of each EI dimension on each 
LMX dimension. Regulation of emotions (control and coordination of the emotions) found to be important on the determination of both Loyalty andContribution dimensions of the LMX.Loyalty refers

To the commitment to the leader and contribution refersto taking extra roles and responsibilities. So instead of behaving due to the urges of emotions, controlling and coordinating the emotions will lead to a high level quality of LMX.

\section{References}

[1] F. Dansereau, G. B. Graen and W. Haga, A Vertical Dyad Linkage Approach to Leadership in Formal Organizations, Organizational Behavior and Human Performance Journal, 13, (1975), 46-78.

[2] E. L. Thorndike, Intelligence and Its Uses, Harper's Magazine, 140, (1920), 227235.

[3] P. Saloveyand J. D. Mayer, Emotional Intelligence. Imagination, Cognition and Personality, 9(3),(1990), 185-211.

[4] G. B. Graen, M. Uhl-Bien, Relationship-Based Approach to Leadership: Development of Leader- Member Exchange (LMX) Theory of Leadership Over 25 Years: Applying a Multi-Level Multi-Domain Perspective, Leadership Quarterly, 6(2),(1995), 219-247.

[5] J. E. Barbuto and M. J. Bugenhagen, The Emotional Intelligence of Leaders as Antecedent to Leader- Member Exchanges: A Field Study, Journal of Leadership Education, 8(2), (2009), 135-146.

[6] M. Kunze and K. Gower, The Influence of Subordinate Affect and Self Monitoring on Multiple Dimensions of Leader - Member Exchange, International Journal of Management \& Marketing Research,5(3),(2012), 83-100.

[7] M. Kunze and J. Phillips, The Influence of Employee Affect on Leader-Member Exchange and Perceptions of Psychological Contract Violation, International Journal of Management \& Marketing Research (IJMMR), 4(3), (2011), 1-23.

[8] S. V. Gils, N. V. Quaquebeke, and D. V. Knippenberg, The X-factor: On the Relevance Of Implicit Leadership And Followership Theories for Leader-Member Exchange Agreement, European Journal of Work and Organizational Psychology, 19(3), (2010), 333-363.

[9] M. C. Mankins, Stop Wasting Valuable Time,Harvard Business Review, 83(9), (2004), 56-67.

[10] C. R. Gerstner and D.V. Day, Meta Analytic Review of Leader-Memner Exchange Theory: Correlates and Construct Issues, Journal of Applied Psychology, 82(6), (1997), 827-844.

[11] R. C. Liden, B. Erdogan, S. Wayne and R. Sparrow, Leader - Member Exchange, Differentiation, and Task Interdependence for Individual and Group Performance, Journal of Organizational Behavior,27, (2006), 723-746.

[12] L. J. Naidoo, C. A. Scherbaum, H. W. Goldstein andG. B. Graen, A Longitudinal Examination of the Effects of LMX, Ability, and Differential on Team Performance, Journal and Business \& Psychology, 26, (2011), 347-357.

[13] P. LeBlanc and G. R. Vicente, A Team level investigation of the relationship between Leader-Member Exchange (LMX) differentiation, and commitment and performance, Leadership Quarterly, 23(3),(2012), 534-544. 
[14] D. T. Hooper, R. Martin, Beyond personal Leader-Member Exchange (LMX) Quality: The Effects of Percieved LMX Variability on Employee Reactions, The Leadership Quarterly, 19(1), Feb(2008), 20-30.

[15] J. Johnson, D. M. Truxillo, B. Erdogan, T. Bauer, L. Hammer, Perceptions of Overall Fairness: Are Effects on Job Performance Moderated by Leader-Member Exchange?,Human Performance, 22,(2009), 432-449.

[16] B. Erdogan, R.C. Liden, M. L. Kraimer, Justice and Leader-Memner Exchange: The Moderating Role of Organizational Culture, Academy of Management Journal, 49(2), (2006), 395-406.

[17] C. A. Schriesheim, S. L. Castro, C. C. Cogliser, Leader - Member Exchange (LMX) Research: A Comprehensive Review of Theory, Measurement and Data - Analytic Practices, Leadership Quarterly, 10(1), (1999), 63-113.

[18] R. M. Dienesch, R. C. Liden, Leader-Member Exchange Model of LEadership: A Critique and Further Development, Academy of Management Review,11(3), (1986), 618-634.

[19] R.C. Liden and J. M. Maslyn, Multidimesionality of Leader-Member Exchange: An Emprical Assessment through Scale Development,Journal of Management,24(1), (1998), 43-72.

[20] G. J. Greguras, J. M. Ford, An Examination of the Multidimensionality of Supervisor and Subordinate Perceptions of Leader-Member Exchange,Journal of Occupational \& Organizational Psychology,79(3), September(2006), 433-465.

[21] N. H. Frijda, The Psychologists' Point of View, in M. Lewis and J. M. Haviland Jones (Eds),Handbook of Emotions (2. nd Ed.), New York, Guilford, 2000.

[22] J. D. Mayer, M. DiPaolo, P. Salovey, Percieving Affective Content in Ambigous Visual Stimuli: A Component of Emotional Intelligence, Journal of Personality Assessment, 54(3\&4), (1990), 772-773.

[23] P. Salovey, J. D. Mayer, Emotional Intelligence, Baywood Publishing Co., New York, 1990.

[24] D. Goleman, 1995, Duygusal Zeka Neden IQ’dan Daha Önemlidir?, Banu Seçkin Yüksel (ed.), 29. ed, Varlık Publications, İstanbul, Turkey, 1995.

[25] M. A. Brackett, J. D. Mayer and R. M. Warner, Emotional Intelligence and Its Relation to Everyday Behaviour, Personality and Individual Differences, 36, (2004), 1387-1402.

[26] K. Thory, A Gendered Analysis of Emotional Intelligence in the Workplace: Issues and Concerns for Human Resource Development, Human Resource Development Review, 12(2),(2012), 221-244.

[27] D. Goleman, Emotional Intelligence: Why It Can Matter More Than IQ, Bloomsbury Publishing, London, 1995.

[28] D. Goleman, Working With Emotional Intelligence, Random House LLC, New York, 2011.

[29] J. D. Mayer and P. Salovey, What is Emotional Intelligence?, in P. Salovey and D. J. Sluyter (Eds), Emotional Development and Emotional Intelligence: Educational Implications, Basic Books, New York, 1997.

[30] A. Cavelzani, M. Esposito and M. Villamira, Emotional Intelligence in Practice, Social Science Research Network (SSRN), January 6, (2009), 89-101.

[31] L. Guillen, Emotional Intelligence and Leadership Effectiveness: The Mediating Influence of Collaborative Behaviors, Journal of Organizational Behavior, February (2011), 1-28. 
[32] C. Cherniss, Emotional Intelligence and Organizational Effectiveness in, in C. Cherniss and D. Goleman (Eds.), The Emotionally Intelligent Workplace, Jossey Bass, San Francisco, 2001.

[33] M.Kotze, I. Venter, Differences in Emotional Intelligence Between Effective and Ineffective Leaders in the Public Sector: An Empirical Study, International Review of Administrative Sciences,72(2), (2011), 397-402.

[34] Y. Hur, P. T. Berg, C. P. M. Wilderom, Transformational Leadership as a Mediator Between Emotional Intelligence and Team Outcomes, The Leadership Quarterly,22,(2011), 591-603.

[35] R. Rajah, Z. Song, R. Arvey, Emotionality and Leadership: Taking Stock of the Past Decade Research, The Leadership Quarterly,22, (2011), 1101-1119.

[36] R. Riggio, R. Reichard, The Emotional and Social Intelligence of Effective Leadership, Journal of Managerial Psychology, 23(2),(2008), 169-185.

[37] J.R. Kennedy-McColl, R. Anderson, Impact of Leadership Style and Emotions on Subordinate Performance,The Leadership Quarterly, 13,(2002),545-559.

[38] J. Luca, P.Tarricone, Does Emotional Intelligence Affect Successful Teamwork?,Edith Cowan University Research Online, (2001), 368-369. http://ro.ecu.edu.au/cgi/viewcontent.cgi?article=5833\&context=ecuworks

[39] A. Pescosolido, Emergent Leaders as Managers of Group Emotion, The Leadership Quarterly, 13, (2002), 582-599.

[40] J. J. Sosik, L. E. Megerian, Understanding Leader Emotional Intelligence and Performance, Group \& Organization Management,24(3), (1999), 367-390.

[41] M. T. Dasborough and N. M. Ashkanasy, Emotion and Attribution of Intentionality in Leader Member Relations,The Leadership Quarterly, 13(5),(2002), 615-634.

[42] J. B. Kellet, R. H. Humphrey and R.G. Sleeth, Empathy and the Emergence of Task and Relations Leaders, The Leadership Quarterly, 17, (2006), 146-162.

[43] P. Jordan and A. Troth, Emotional Intelligence and Leader Member Exchange; The Relation with Employee Turnover Intentions and Job Satisfaction,Leadership and Organizational Development Journal, 32(3), (2011), 260-280.

[44] C. Wong, K. S. Law, TheEffects of Leader and Follower Emotional Intelligence on Performance and Attitude: An Exploratory Study, The Leadership Quarterly, 13, (2002), 243-274.

[45] J. Lee, Effects of Leadership and Leader - Member Exchange on Commitment, Leadership and Organizational Develeopment Journal, 26(8), (2005), 665-672. 


\section{Appendix}

\section{A.1. Emotional intelligence items}

Self-emotion appraisal (SEA)

1. I have a good sense of why I have certain feelings most of the time.

2. I have good understanding of my own emotions.

3. I really understand what I feel.

4. I always know whether or not I am happy.

Others' emotion appraisal (OEA)

5. I always know my friends' emotions from their behavior.

6. I am a good observer of others' emotions.

7. I am sensitive to the feelings and emotions of others.

8. I have good understanding of the emotions of people around me.

Use of emotion (UOE)

9. I always set goals for myself and then try my best to achieve them.

10. I always tell myself I am a competent person.

11. I am a self-motivated person.

12. I would always encourage myself to try my best.

Regulation of emotion (ROE)

13. I am able to control my temper and handle difficulties rationally.

14. I am quite capable of controlling my own emotions.

15. I can always calm down quickly when I am very angry.

16. I have good control of my own emotions

\section{A.2. Leader Member Exchange Items}

Subordinate perspective

Affect dimension (AFF)

(1) I like my supervisor very much as a person.

(2) My supervisor is the kind of person one would like to have as a friend.

(3) My supervisor is a lot of fun to work with.

Loyalty dimension (LOY)

(4) My supervisor defends my work actions to a superior, even without completeknowledge of the issue in question.

(5) My supervisor would come to my defence if I were 'attacked' by others.

(6) My supervisor would defend me to others in the organization if I made an honestmistake.

Contribution dimension (CON)

(7) I do work for my supervisor that goes beyond what is specified in my jobdescription.

(8) I am willing to apply extra efforts, beyond those normally required, to meet mysupervisor's work goals.

(9) I do not mind working my hardest for my supervisor.

Professional respect (RES)

(10) I am impressed with my supervisor's knowledge of his/her job.

(11) I respect my supervisor's knowledge of and competence on the job.

(12) I admire my supervisor's professional skills. 